\title{
THE EFFECT OF CONSUMERS’ ATTITUDES TOWARDS LOGOS OR EMBLEMS ON BRAND PREFERENCE
}

\author{
Sevda DENEÇLI $\dot{I}^{*}$
}

\begin{abstract}
This study, which has attempted to identify the effects of the attitude of consumers towards the brand logos or emblems on their preference for particular brands, has been carried out on 127 people through convenience sampling. Within the scope of the study, two international sports clothing brands, which are the most popular in the Turkish market, have been discussed, one of these using logos and the other using emblems. In the study, correlation analysis has been used to identify the relationship between the attitudes of consumers towards the logos and emblems of brands which use one or other of them and their preference between brands, while multiple regression analysis has been used to identify the effect of the attitude of consumers towards the logos and emblems of brands on their preference for particular brands. In this manner, the effect of the use of logos or emblems by brands on brand preference is analysed comparatively, by taking into consideration individuals who use or do not use brands which use logos or individuals who use or do not use brands which use emblems.
\end{abstract}

Keywords: Logo, Emblem, Brand, Brand Preference.

\section{TÜKETICIILERINN MARKALARIN LOGO YA DA AMBLEMLERİNE KARŞI TUTUMLARININ MARKA TERCIHHLERİ ÜZERINNDEKİ ETKİSI}

\section{Özet}

Tüketicilerin markaların logo ya da amblemlerine karşı tutumlarının marka tercihleri üzerindeki etkisinin belirlenmeye çalışıldığı bu araştırma kolayda örnekleme yöntemiyle 127 kişi üzerinde gerçekleştirilmiştir. Araştırma kapsamında Türkiye pazarında en popüler olan, biri logo biri de amblem kullanan uluslararası iki spor giyim markası ele alınmıştır. Araştırmada tüketicilerin logo ve amblem kullanan markaların logo ve amblemlerine ilişkin tutumları ile marka tercihleri arasındaki ilişkiyi belirlemek amacıyla korelasyon analizi; tüketicilerin markaların logo ve amblemlerine karşı tutumlarının marka tercihleri üzerindeki etkisini belirlemek amacıyla ise çoklu regresyon analizi kullanılmıştır. Bu şekilde markanın

* Nisantasi University, Faculty of Economics and Administrative Sciences, Department of Public Relations and Advertising, Assist. Prof.Dr. 
logo ya da amblem kullanımının marka tercihi üzerindeki etkisi; logoyu kullanan markayı kullanan ya da kullanmayan bireyler ve amblem kullanan markayı kullanan ya da kullanmayan bireyler dikkate alınarak karşılaştırmalı olarak analiz edilmiştir.

Anahtar Kelimeler: Logo, Amblem, Marka, Marka Tercihi.

\section{INTRODUCTION}

The competitive conditions, which have been increasing daily in the economic environment that has been developing and growing since the Industrial Revolution, have brought great hardships on companies in terms of maintaining their existence. Companies therefore carry out marketing activities with the purpose of creating trust in consumers and making their products stand out from other products, thus claiming their place in the market by becoming distinct in comparison with their rivals.

The concept of a brand, which differentiates a company from other companies and gives consumers quality assurance and guarantees, should firstly embody an accurate identity study. Corporate identity, which expresses a company's role and function and is used to transmit a company's targets and values, can be presented to consumers in various visual aspects. One of the most important of these visual aspects is a logo [1] [2].

Individuals are confronted with the logos of the different brands around them throughout the day. A brand's logo is the symbolic representation of the brand and functions as a visual image that shapes brand association in the minds of the consumers. The logos of brands play a leading role in terms of the connections to be formed between consumers and particular brands and provide a "tangible asset" in relation to the brand in the consumers' minds [3]. Individuals can remember certain logos and emblems among the numerous logos and emblems they come across. Additionally, individuals feel close to some of these logos and emblems they remember and distant to others. It can be said that the attitude created as a result of the interaction between consumers and logos and emblems may have an effect on consumers' brand preferences. Therefore, the impact of the use of logos and emblems, which are among the visual aspects of branding, on consumers' brand preference will be analysed in this study.

\section{LOGOS, EMBLEMS AND CONSUMER ATTITUDE}

Companies wish to tell their target groups who they are, what they do and how they do things. Corporate identities, created for this purpose, allow companies to become distinctive in comparison with their rivals and to introduce themselves as companies to consumers. Although corporate identity involves numerous components, when corporate identity is under discussion, the first ideas that spring to mind are the company's logo and emblem [2]. When they are taken into consideration in terms of corporate identity, logos act as signatures on all 
the materials and products used by a company. Logos can involve various graphic and typographic aspects [4].

A logo, which is an abbreviation of the word "logotype", (a combination of the word "logos" ( $\lambda$ ójoc), meaning statement or discourse in Greek and the suffix “type", meaning writing) serves as a mediator between corporate identity and the perception of companies by consumers. However, the expectation of consumers that the brand they prefer should be of good quality is an issue to which importance should be attached. This expectation of consumers is generally quite high. This long-term assurance which quality guarantees provide shapes the foundation of the relationship between consumers and producers [5]. It can be stated that logos, which are the most important of the components of corporate identity, play an effective role in supplying information about brand quality and brand power to consumers, who are in expectation of good quality from their chosen brands.

For instance, when the McDonald's chain is mentioned, most people probably visualize the gold belt of the McDonald's brand. In this example, the fact that the first thing coming to people's mind is the gold belt of McDonald's, even before the products of the brand, shows how powerful a brand identity this company has and how important identity is [6].

Today, logos which are unique to a company or a brand, not used by other companies or brands and are signs recognised by consumers, are recognised to have existed even in very ancient periods of human history. Stone carvers engraved signs unique to them on their works, just like today's carpenters; Roman slave owners had tattoos made on their slaves, indicating their ownership of them; aristocrats and soldiers used shields decorated with coats of arms. All these shed light on the history of logos [5].

On the other hand, some corporate logos used today were first used in the 1880's by brands such as Campbell Soaps, HJ. Heins Pickles and Quaker Oat Cereals. These brands reached millions with their corporate logos. Consumers, who felt uneasy about buying products with which they were not familiar, began to recognise the products of certain companies and differentiate these from the others by means of the logos used by the companies in their packaging [7].

Creating familiarity with brands requires the creation of powerful and unique brand associations. This is possible by the use of elements of brand identity, such as brand names, logos and symbols, and by integrating brand identity with the marketing programmes adopted by the companies [8]. Logos are only one component of branding and serve as 'visual delegates'. Designers suggest that an accurately designed logo should create a desire for that brand in the observer [9].

Logos are created by bringing together two or more typographic characters, which can be read as a word. They are defined as symbols that carry a brand or emblem characteristic, which serve to promote a product, company or service [10]. Logos can take various forms. They display variety in that they can be written in a manner which distinguishes them as a text only, 
consisting of the words of the company names or brands, or as abstract designs that are totally unrelated to the company names, the activities carried out by the company, or any other words related to them [11]. Some logos incorporate social identities, such as uncle, aunt, doctor, with which people are familiar, for instance, Uncle Ben or Dr. Brown. These types of logos take the place of traditional local shopkeepers who provide assurance to consumers, creating an interface between the products associated with them and the consumers [7].

Some companies design their logos in the form of typographical, figurative, or abstract images, or a combination of these. For instance, while the logo of the Coca Cola brand is a typographical logo which has a certain font and colour harmony, the Shell Company uses the mussel shell image as a symbol. Generally, logos of car brands are abstract logo designs [12]. The star of the Mercedes brand could be given as an example of an abstract logo design. The crown of the Rolex brand, the logo of the Nike brand and the Olympic hoops are sign logos which do not contain words and they are generally referred to as symbols [11]. Symbols, which do not include the word characteristic, are created with abstract or objective images or letters and can be referred to as emblems [10]. Although logos and emblems have differences, they bear certain similarities: they are simple and memorable; they display different and distinctive features; they are sometimes of a single colour and multi-coloured at other times; they transmit the desired message of the brands clearly to the consumers; they can be applied to all sorts of surfaces through different printing techniques and they can be redesigned in accordance with the current trend in a manner which is open to new developments in the changing world [13].

Logos are widely used on products, packages, promotional materials, advertisement boards, clothing, buses, taxis, buildings, theatres, televisions and computers. It can be seen that over time, certain changes are made to the dimensions, colour and other characteristics of logos. The words “Coca Cola”, for instance, have been written in various different typefaces throughout the history of the brand [14]. Similarly, with reference to the brands in Turkey, the changes made to the logo of the Arçelik Company can also be observed.

Logos play a significant role in the social relationship between consumers and companies for two basic reasons which complement each other. They give information to consumers about particular products before they buy them [5]. Positive emotional reactions are important to the success of a logo. The reason for this is that the emotions generated by logos are transferred to the products or companies by the consumers [4]. After buying a particular product, consumers who have experienced the product will associate their perception of it with its logo every time they see it [5]. For instance, a consumer who buys and is not satisfied with a product will retain the association of the inferior quality of the product with the product's logo whenever he sees it.

Logo recognition takes place on two levels. The first level is that consumers need to remember logos when they see them. The second level is that logos remind consumers of the names of brands or companies. This reminder is firstly dependent on the logo design. It has been observed that when consumers have been subjected equally to a range of logos, those with a 
simple design are easier to remember. Therefore, brands should design their logos in a manner which makes them easily recognisable or memorable [4].

In order for the messages transmitted by brands to consumers to create a particular attitude in the consumers, various functions, such as the utility function, the valuation function, the ego defence function and the information function, can be effective. The liking and use of brands by consumers which satisfy their needs is related to the utility function; resolving psychological deficiencies by buying certain brands in order to feel better is related to the ego defence function; the need of individuals to acquire information which helps them understand the events or objects which influence them is related to the information function; the use of brands which allow individuals to express their identities is related to the valuation function [11][15][16].

Valuation means the expression by consumers of their central values, or the values or individual preferences which are important to them; in other words, their identities [15]. Individuals communicate with the external world through the products or services they use or consume and use these products as a means of communication [16]. While consumers develop attitudes towards products or brands, they do not do this merely in accordance with the objectives and rational characteristics of these brands or products, but in accordance with the personal meanings that they themselves attach to them [15] [17]. Logos show visually what brands are and what they symbolise. At the same time, they provide the focal point in establishing communication with consumers by transmitting the core values of the brands to them. In other words, logos create associations between the individuals themselves and the brands in question and cause individuals to see the brands as an extension of them [11] [18]. It can also be seen that consumers take into consideration whether the brands they choose after evaluating them then provide a functional value or not.

Functional value is related to functionality and other physical characteristics. Physical characteristics are generally related to performance, durability, reliability, features of products and price. Functional characteristics take a very important place in consumers' decisions related to brands [19]. Logos, which represent brands visually, have the power to transmit to the consumers what the functional benefits of a brand are [18]. Besides placing importance on functionality when choosing the products or brands they will be using, sometimes it can also be important for consumers that these products or brands should be aesthetically pleasing.

Aesthetical products grab the attention of consumers and have an effect on the consumers' perceptions. In particular, the design factor is very important in attracting attention [20]. Many studies have been conducted on how consumers react to the aesthetics of a brand, for instance, on product design and its psychological aspects. Logos are one of the important aspects of brand aesthetics. It is for this reason that companies redesign their logos to make them more attractive to their current customers and to acquire new customers [21]. Besides providing visual pleasure for consumers, being aesthetically attractive to people allows them to feel affinity with these logos and causes them to form emotional connections with the brands they represent [18]. 
When the literature is analysed, it is possible to find many studies on logos. Gerrard et al. (2013) have analysed in their study whether English consumers were influenced by the logos of organic products in terms of buying them. As a result of the study, it has been determined that these logos give assurance to consumers and when they see logos indicating that these products are organic, they are willing to pay higher prices than for products which do not have these logos or which have logos which are not widely known [22]. Van Riel et al. (2001) have stated in their study that consumers identify each logo with different associations and concepts. The study aimed to identify what consumers remember when they come across a new logo. It was determined that when individuals see the logo of a company they are familiar with, its logo creates a smaller number of associations in the individuals, whereas a logo (of a bank, for example) which they are seeing for the first time creates more associations [23].

In another study, the logos belonging to three different categories, which consisted of brands of products used by children aged three to six, brands of products used by adults and different cigarette brands, were shown to children and it was attempted to determine whether the children recognised these logos or not. As a result of the study, it was discovered that the children mostly recognised the logos and, in particular, that their rate of recognition increased as their ages increased [24]. Another study, again involving children, analysed whether children's recognition of logos has any effect on their eating behaviour or food preferences. The study involved 475 children and it was determined that $88 \%$ of these children recognised at least 16 of the 20 logos shown to them. However, a relationship between the high logo recognition rate and children's eating habits or food preference has not been determined [25]. Henderson and Cote (1998) have attempted to determine in their study what characteristics logos should have in order to provide the desired corporate image. In this study, 195 logos were evaluated with reference to 13 design characteristics. As a result of the study, it was found that logos which are widely recognised are natural, harmonious and partly detailed and that logos with more complex images should be natural and partly detailed as well [4]. Walsh et al. (2011) have attempted in their study to determine what kinds of reactions consumers had to logos which were initially hard-edged but were redesigned to be more curvy, how consumers' commitment to brands affects the redesigning of them and what the attitude of consumers is towards brands. As a result of their study, they have determined that the commitment of consumers towards particular brands creates a negative effect when they evaluate the changed logos and this negative evaluation has an effect on their attitude towards the brands. In the literature, there are many more studies on logos [21]. However, no studies have been discovered which deal with the way in which logos containing words and emblems, which do not have word characteristics, create a difference in consumers' evaluation of brands. 


\section{AIM AND METHOD}

"Logos" which contain words and "emblems" which do not have word characteristics allow companies and brands to establish visual communication with consumers. When the literature is analysed, it can be seen that logos and emblems are all dealt with as "logos", without distinguishing one from the other in the studies. However, this raises the problem of whether logos or emblems have more effect on consumers. In view of this, in this study, the aim has been to determine the effect on consumers' brand preferences of using logos or emblems.

Within the scope of the study, the two most popular international sports clothing brands in the Turkish market have been examined. The reason why these brands have been preferred is that one of them mainly uses logos on its products, while the other mainly uses emblems. In this manner, it has been possible to analyse comparatively the effect of the brands' use of logo versus emblem on brand preference. Accordingly, the attitude of consumers towards the brands' logos or emblems has been adopted as the independent variable and brand preference as the dependent variable. In addition, other aspects which can have an effect on consumers' attitude towards brand logos or emblems, namely, the frequency of use of a brand, satisfaction with a brand's products and brand commitment have been adopted as control variables.

The following hypotheses have been developed to be tested in the study:

1. H1: The attitude of consumers who (a) use and (b) do not use the brand which uses a logo towards the brand's logo influences their brand preference.

2. H1: The attitude of consumers who (a) use and (b) do not use the brand which uses an emblem towards the brand's emblem influences their brand preference.

\section{III.1. Participants}

The study has been conducted on 127 people who have been selected through the convenience sampling method. The research has been implemented on the Internet. With regard to this, the survey used in the study has been shared on various social media platforms with the users.

$58 \%$ of the participants are males and $86 \%$ are between the ages 18 and $29.64 \%$ of the participants are university graduates and the income level of $62 \%$ is between $1.000 \mathrm{TL}$ and 5.000 TL (Table 1). $77 \%$ of the participants $(n=98)$ have stated that they use the brand, which makes use of an emblem, and $70 \%(n=89)$ have stated that they actively use the brand which makes use of a logo. 
Table 1: Demographical Data

\begin{tabular}{|l|l|c|c|}
\hline \multicolumn{2}{|l|}{ Demographical Variables } & Frequency & Percentage \\
\hline Sex & Male & 74 & 58 \\
\hline & Female & 53 & 42 \\
\hline Age & $18-24$ & 44 & 35 \\
\hline & $25-9$ & 65 & 51 \\
\hline & $30-39$ & 10 & 8 \\
\hline Education & 40 and over & 8 & 6 \\
\hline & High School & 34 & 27 \\
\hline & University & 81 & 64 \\
\hline Income Level & Postgraduate & 12 & 9 \\
\hline & Less than 1.000 TL & 25 & 20 \\
\hline & 1.000 TL-2.999TL & 41 & 32 \\
\hline & 3.000 TL-4.999 TL & 38 & 30 \\
\hline & 5.000 TL and over & 23 & 18 \\
\hline & & & \\
\hline
\end{tabular}

\section{III.2. Data Collection Tool}

In the study, in order to evaluate the participants' brand preference, the scale developed by Sirgy et al. (1997) has been used. The scale consists of a total of three expressions in the 5-point Likert scale (5: I totally agree; 1 : I totally do not agree) (example expression: "I would be inclined to buy a 'focal brand' over a 'referent brand"') [26]. According to this, higher scores indicate that the person prefers the brand in comparison to other brands, whereas lower scores indicate the opposite. The Cronbach's Alpha value calculated for the score is 0,86.

In the study, in order to measure consumers' attitude towards the brands' logos or emblems, the scale developed by Park et al. (2013) has been used. The scale analyses the attitude towards the brands' logos or emblems in four dimensions (Logo/Emblem identification, Functional benefit, Aesthetic appeal, Self-identity/ Expressiveness Benefit). The scale consists of a total of 12 expressions arranged in the 5-point Likert scale (5: I totally agree; 1: I totally do not agree). In the scale, there are three expressions for each dimension. According to this, a high score received in the "Logo/Emblem identification" dimension (example expression: “[Brand name]'s logo helps me identify the brand") indicates that the person can easily recognise the brand from its logo or emblem; a high score received in the "Functional benefit" dimension (example expression: "[Brand name]'s logo reassures me that the brand .93 assists me in handling my daily life competently") indicates that the person thinks that the brand's logo or emblem successfully 
symbolises the aspects he expects from the brand; a high score received in the "Aesthetic appeal" dimension (example expression: “[Brand name]'s logo is aesthetically (visually) pleasing to me) indicates that the person finds the brand's logo or emblem aesthetically pleasing; and a high score received in the "Self-identity/ Expressiveness Benefit" dimension (example expression: "[Brand name]'s logo makes me think that [brand name] expresses who I am as a person") indicates that the person thinks that the brand's logo or emblem effectively helps him to express himself as an individual [18]. The Cronbach's Alpha values calculated for the dimensions in the scale range between 0,89 and 0,93 .

In the study, the frequency of use of the brands by the participants has been evaluated with a single expression arranged in the 5-point Likert scale (5: very frequently; 1: never) ("I use the products of this brand"). In order to measure the satisfaction the participants felt with the brands' products, the scale developed by Westbrook and Oliver (1981) has been used [27]. The scale consists of a total of twelve expressions arranged in the 5-point Likert scale (example expression: "I am satisfied with my decision to buy this brand"). The Cronbach's Alpha value calculated for the scale is 0,89 . The participants' commitment level to the brands has been evaluated through the scale developed by Putrevu and Lord (1994) [28]. The scale consists of a total of three expressions arranged in the 5-point Likert scale (5: I totally agree; 1 : I totally do not agree) (example expression: "I always purchase the above brand of [product]"). The Cronbach's Alpha value calculated for the scale is 0,92 .

\section{III.3. Statistical Analysis}

In the study, in order to determine the relationship between the consumers' attitude towards the logos or emblems of brands which use them and their brand preference, correlation analysis has been carried out. In order to determine the effect of consumers' attitude towards the brands' logos and emblems on their brand preference, multiple regression analysis has been used. In order to determine whether the control variables differed for the two brands, the paired-samples " $\mathrm{t}$ " test has been used.

\section{III.4. Findings}

In the study, when the consumers' levels of preference for the sports clothing brands which are the subject of the study (Table 2) are examined, it can be seen that their preferences are split between both brands (Brand which uses a $\operatorname{Logo}=3,22$; Brand which uses an Emblem=3,49). According to the results of the paired-samples " $\mathrm{t}$ " test $(\mathrm{t}=1,68 \mathrm{p}>0,05)$, the two brands are similar to each other in terms of brand preference. From the results attained from the levels of frequency of using the brand, satisfaction felt towards the brand's products and commitment to the brand, which have been taken as control variables (Table 2), it can be seen that consumers frequently use the products of both brands (Brand which uses a Logo=3,94; Brand which uses an 
Emblem $=3,90 ; t=0,43 p>0,05)$; they are close to being satisfied by the products of both brands (Brand which uses a Logo $=3,88$; Brand which uses an Emblem $=3,98 ; t=0,73 \mathrm{p}>0,05$ ) and they are committed to both brands in equal measure (Brand which uses a Logo $=2,68$; Brand which uses an Emblem $=2,70 ; t=1,46 p>0,05)$. That the control variables do not display differences to any significant degree shows that consumers' attitudes towards the logos and emblems of these brands are equally affected by the variables in question. Consequently, the possible effects of the control variables on the results of the study remain fixed.

Table 2: Average and Standard Deviation Values Related to Dependent Variable and Control Variables and Paired-samples " $t$ " Test Results

\begin{tabular}{|l|c|c|c|c|c|c|}
\hline & \multicolumn{2}{|c|}{$\begin{array}{c}\text { Results for the Brand } \\
\text { which Uses a Logo }\end{array}$} & \multicolumn{2}{|c|}{$\begin{array}{c}\text { Results for the } \\
\text { Brand which Uses an } \\
\text { Emblem }\end{array}$} & \multicolumn{2}{|c|}{$\begin{array}{c}\text { Results of the Paired- } \\
\text { samples “t” Test }\end{array}$} \\
\hline & O & SS & O & SS & $\mathrm{t}$ & $\mathrm{p}$ \\
\hline Brand Preference & 3,22 & 0,96 & 3,49 & 1,12 & 1,68 & 0,10 \\
\hline $\begin{array}{l}\text { Frequency of Brand } \\
\text { Usage }\end{array}$ & 3,94 & 0,96 & 3,90 & 0,80 & 0,43 & 0,67 \\
\hline $\begin{array}{l}\text { Satisfaction Felt } \\
\text { Toward the Products } \\
\text { of the Brand }\end{array}$ & 3,88 & 0,91 & 3,98 & 1,00 & 0,73 & 0,47 \\
\hline Brand Commitment & 2,68 & 0,99 & 2,70 & 1,14 & 1,46 & 0,88 \\
\hline
\end{tabular}

The results achieved from the related scale on consumers' attitudes towards the logos and emblems of the brands can be summarised as follows (Table 3 and 4): Consumers express that they can identify both of the brands from their logos or emblems (Brand which uses a Logo $=3,70$; Brand which uses an Emblem =4,26); however, the levels of consumers' correct identification of the brand to which the emblem belongs is relatively higher than that of the brand which uses an emblem. Consumers express that the logos or emblems of both brands partly symbolise the functional benefits they expect from the brand (Brand which uses a Logo $=2,84$; Brand which uses an Emblem=3,32). On the other hand, consumers find the emblem of the brand which uses an emblem more aesthetic in comparison with the logo of the brand which uses a logo (Brand which uses a Logo= 2,94; Brand which uses an Emblem=3,89). In addition to this, consumers think that the logo of the brand which uses a logo does not help them to express themselves as individuals; however, they think that the emblem of the brand which uses an emblem partly helps them in that respect (Brand which uses a Logo $=2,43$; Brand which uses an Emblem $=2,78$ ). 
In the study, when the relationship between the aspects of the attitude towards the logo or the emblem and consumers' brand preference are analysed for both brands (Table 3 and 4), it can be seen that each aspect of the attitude towards the logo or the emblem for both brands has a significant relationship with consumers' brand preference. The relationship in question is positive for all aspects and is of medium level $(0,40<\mathrm{r}<0,70)$. According to this, as consumers attitude towards the logo or emblem of both brands increases positively, their brand preference also increases positively. On the other hand, it can be seen that all aspects of attitude also have a positive significant relationship with each other at a medium level. With reference to this, it can be stated that the different aspects of the attitudes of consumers towards the logo or emblem of both brands are interacting with one another.

Table 3: Average and Standard Deviation Values Obtained from Scales Related to the Brand which Uses a Logo and Results of the Correlation Analysis

\begin{tabular}{|l|c|c|c|c|c|c|c|}
\hline & A & SD & (1) & (2) & (3) & (4) & (5) \\
\hline (1) Brand Preference & 3,22 & 0,96 & 1,00 & & & & \\
\hline (2) Identification & 3,70 & 0,87 & $0,49^{* *}$ & 1,00 & & & \\
\hline (3) Functional Benefit & 2,84 & 0,96 & $0,53^{* *}$ & $0,55^{* *}$ & 1,00 & & \\
\hline (4) Aesthetic Appeal & 2,94 & 1,11 & $0,47^{* *}$ & $0,59^{* *}$ & $0,51^{* *}$ & 1,00 & \\
\hline $\begin{array}{l}\text { (5)Self-identity/ } \\
\text { Expressiveness Benefit }\end{array}$ & 2,43 & 0,99 & $0,45^{* *}$ & $0,38^{* *}$ & $0,51^{* *}$ & $0,56^{* *}$ & 1,00 \\
\hline
\end{tabular}

${ }^{\star} \mathrm{p}<0,05{ }^{\star *} \mathrm{p}<0,01$

Table 4: Average and Standard Deviation Values Obtained from Scales Related to the Brand which Uses an Emblem and Results of the Correlation Analysis

\begin{tabular}{|l|c|c|c|c|c|c|c|}
\hline & A & SD & (1) & (2) & (3) & (4) & (5) \\
\hline (1) Brand Preference & 3,49 & 1,12 & 1,00 & & & & \\
\hline (2) Identification & 4,26 & 0,77 & $0,40^{* *}$ & 1,00 & & & \\
\hline (3) Functional Benefit & 3,32 & 1,07 & $0,48^{* *}$ & $0,48^{* *}$ & 1,00 & & \\
\hline (4) Aesthetic Appeal & 3,89 & 0,99 & $0,42^{\star *}$ & $0,59^{* *}$ & $0,53^{* *}$ & 1,00 & \\
\hline $\begin{array}{l}\text { (5)Self-identity/ } \\
\text { Expressiveness Benefit }\end{array}$ & 2,78 & 1,02 & $0,41^{\star *}$ & $0,41^{* *}$ & $0,56^{* *}$ & $0,44^{* *}$ & 1,00 \\
\hline
\end{tabular}

${ }^{*} \mathrm{p}<0,05^{* *} \mathrm{p}<0,01$

In order to determine the effect of consumers' attitudes towards the logo or the emblem on their brand preference, a series of multiple regression analyses has been carried out. The regression analysis has been carried out separately for each brand with reference to consumers who use the brand and consumers who do not use the brand. 
As a result of the regression analysis carried out to determine the effect of the attitudes towards the brand's logo of consumers who use the brand which uses a logo and those who do not use it on their brand preference (Table 5), a significant model has been achieved for both consumer groups (those who use the Brand $\mathrm{R} 2=0,23 \mathrm{~F}=6,28 \mathrm{p}=0,00<0,01$; those who do not use the Brand $\mathrm{R} 2=0,48 \mathrm{~F}=7,50 \mathrm{p}=0,00<0,01$ ) (Hypothesis 1a and $1 \mathrm{~b}$ Accepted). These models indicate that the level of the effect of consumers' attitudes towards the logo on their brand preference is $13 \%$ for those who use the brand and $48 \%$ for those who do not use the brand.

According to the model achieved as a result of the analysis carried out for consumers who use the brand which uses a logo, it has been determined that only the Functional Benefit aspect of attitude towards the logo (Standard Beta $=0,26 \mathrm{p}=0,04<0,05$ ) has a significant impact on the level of consumers' brand preference. The impact in question is positive. According to this, as the perception of consumers that the brand's logo symbolises the characteristics they expect from the brand gets stronger, their level of brand preference increases.

According to the model achieved as a result of the analysis carried out for consumers who do not use the brand which uses a logo, it has been determined that only the logo identification aspect of attitude towards the $\operatorname{logo}($ Standard Beta $=0,58 \mathrm{p}=0,01<0,05$ ) has a significant impact on the level of consumers' brand preference. The impact in question is positive. According to this, as the level of recognition of consumers who do not use the brand which uses a logo increases, their level of brand preference increases. It is noteworthy that in each of the consumer groups different aspects of attitude come to the foreground.

As a result of the regression analysis carried out in order to determine the effect of the attitudes towards the brand's emblem of consumers who use the brand which uses an emblem and those who do not use it on their brand preference (Table 6), a significant model has been achieved only for the consumer group which uses the brand (Those who use the Brand $\mathrm{R} 2=0,26 \mathrm{~F}=8,30 \mathrm{p}=0,00<0,01$; Those who do not use the Brand $\mathrm{R} 2=0,21 \mathrm{~F}=1,56 \mathrm{p}=0,28>0,05$ ) (Hypothesis 2a Accepted; 2b Rejected). According to this, it can be seen that the attitude of consumers who do not use the brand towards the emblem does not have a significant impact on their brand preference. For consumers who do use the brand, the model indicates that the level of the effect of consumers' attitudes towards the emblem on their brand preference is $26 \%$.

According to the model achieved as a result of the analysis carried out for consumers who use the brand which uses an emblem, it has been determined that only the Functional Benefit aspect (Standard Beta $=0,35 \mathrm{p}=0,01<0,05$ ) of attitude towards the emblem has a significant impact on the level of consumers' brand preference. The impact in question is positive. According to this, with reference to consumers who do use the brand using an emblem, as the level of perception that the emblem of the brand symbolises the characteristics expected of it increases, their levels of brand preference also increase. This result is in parallel with the results of the analysis carried out for consumers who use the brand which uses a logo. 
Table 5: Results of the Regression Analysis Related to the Effect of Consumers' Attitudes towards the Logo of the Brand which Uses a Logo

\begin{tabular}{|l|c|c|c|c|c|c|c|c|c|c|}
\hline & \multicolumn{4}{|c|}{ Those who use the brand } & \multicolumn{3}{c|}{ Those who do not use the brand } \\
\hline & B & $\begin{array}{c}\text { Stand- } \\
\text { ard } \\
\text { Error }\end{array}$ & $\begin{array}{c}\text { Stand- } \\
\text { ard } \\
\text { Beta }\end{array}$ & $\mathbf{t}$ & $\mathbf{p}$ & $\mathbf{B}$ & $\begin{array}{c}\text { Stand- } \\
\text { ard } \\
\text { Error }\end{array}$ & $\begin{array}{c}\text { Stand- } \\
\text { ard } \\
\text { Beta }\end{array}$ & t \\
\hline (Fixed) & 1,62 & 0,48 & & 3,41 & $0,00^{* *}$ & 0,34 & 0,46 & & 0,74 & 0,46 \\
\hline Identification & 0,12 & 0,15 & 0,10 & 0,81 & 0,42 & 0,61 & 0,22 & 0,58 & 2,81 & $0,01^{*}$ \\
\hline Functional Benefit & 0,25 & 0,13 & 0,26 & 2,10 & $0,04^{*}$ & 0,04 & 0,29 & 0,04 & 0,13 & 0,90 \\
\hline Aesthetic Appeal & 0,10 & 0,11 & 0,12 & 0,91 & 0,37 & $-0,16$ & 0,20 & $-0,17$ & $-0,83$ & 0,42 \\
\hline $\begin{array}{l}\text { Self-identity/ Expres- } \\
\text { siveness Benefit }\end{array}$ & 0,10 & 0,12 & 0,11 & 0,84 & 0,41 & 0,36 & 0,25 & 0,35 & 1,45 & 0,16 \\
\hline
\end{tabular}

Dependent Variable: Brand Preference

Those who use the brand: $\mathrm{R} 2=0,23 \mathrm{~F}=6,28 \mathrm{p}=0,00<0,01$

Those who do not use the brand: $\mathrm{R} 2=0,48 \mathrm{~F}=7,50 \mathrm{p}=0,00<0,01$

${ }^{* *} \mathrm{p}<0,01{ }^{*} \mathrm{p}<0,05$

Table 6: Results of the Regression Analysis Related to the Effect of Consumers' Attitudes towards the Emblem of the Brand which Uses an Emblem

\begin{tabular}{|c|c|c|c|c|c|c|c|c|c|c|}
\hline & \multicolumn{4}{|c|}{ Those who use the brand } & \multicolumn{3}{c|}{ Those who do not use the brand } \\
\hline & B & $\begin{array}{c}\text { Stand- } \\
\text { ard } \\
\text { Error }\end{array}$ & $\begin{array}{c}\text { Stand- } \\
\text { ard } \\
\text { Beta }\end{array}$ & $\mathbf{t}$ & $\mathbf{p}$ & $\mathbf{B}$ & $\begin{array}{c}\text { Stand- } \\
\text { ard } \\
\text { Error }\end{array}$ & $\begin{array}{c}\text { Stand- } \\
\text { ard } \\
\text { Beta }\end{array}$ & $\mathbf{p}$ \\
\hline (Fixed) & 1,57 & 0,78 & & 2,04 & $0,04^{*}$ & 1,19 & 0,68 & & 1,74 & 0,09 \\
\hline Identification & 0,02 & 0,20 & 0,01 & 0,09 & 0,93 & 0,32 & 0,23 & 0,35 & 1,38 & 0,18 \\
\hline Functional Benefit & 0,33 & 0,12 & 0,35 & 2,83 & $0,01^{*}$ & 0,35 & 0,27 & 0,38 & 1,28 & 0,21 \\
\hline Aesthetic Appeal & 0,14 & 0,13 & 0,12 & 1,12 & 0,27 & 0,05 & 0,21 & 0,07 & 0,26 & 0,79 \\
\hline $\begin{array}{c}\text { Self-identity/ Ex- } \\
\text { pressiveness Benefit }\end{array}$ & 0,13 & 0,11 & 0,14 & 1,21 & 0,23 & $-0,47$ & 0,230 & $-0,46$ & $-1,59$ & 0,13 \\
\hline
\end{tabular}

Dependent Variable: Brand Preference

Those who use the brand: $\mathrm{R} 2=0,26 \mathrm{~F}=8,30 \mathrm{p}=0,00<0,01$

Those who do not use the brand: $\mathrm{R} 2=0,21 \mathrm{~F}=1,56 \mathrm{p}=0,28>0,05$

${ }^{* *} \mathrm{p}<0,01{ }^{*} \mathrm{p}<0,05$ 


\section{CONCLUSION}

Corporate identity, which allows companies to express themselves in their communication with their target groups, encompasses who the company is and how it wishes to be perceived by its target groups, while transmitting information about the company to the target group. Similarly, all its various aspects, such as brand names, logos, symbols, wrapping, packages, etc., create brand identity by contributing to brand awareness and brand image [11]. Brand identity, which is made up of many different components, establishes the initial communication with consumers through visual aspects, such as logos, emblems, colours, etc., and grabs their attention. Therefore, companies or brands attach great importance to their logos and emblems within the context of visual communication, which is the first step in their relationship with consumers. They give prominence to logos and emblems in such a way as to distinguish themselves from their rivals, to make themselves remembered more easily and to ensure a high level of recognition when they are seen.

Logos, which are unique to companies or brands and allow them to be distinct from other companies or brands, have been used for many years. Logos and emblems help to create a visual familiarity in the minds of consumers with particular brands and create unique brand associations. They help consumers to create an association related to a particular product or brand, both prior to the buying process and afterwards. When consumers see logos or emblems, whether they recognise or remember the brands to which the logos belong is related to the design of the logos or emblems. The colours of logos and emblems, whether they have simple or complex designs and other similar aspects can be important in enabling consumers to evaluate the functionality or aesthetic qualities of a brand, or to establish whether or not they feel an affinity with a brand and in this manner form an emotional connection with it.

In literature, various studies related to the relationship between logos and consumer behaviours can be found. However, this study has attempted to determine what differences are displayed in consumers' evaluation of brands with logos which contain words and emblems which do not have word characteristics and also to determine the effect of the use of logo versus emblem on consumers' brand preferences. Therefore, two sports brands have been the subjects of the study, one being a brand which mainly uses a logo and other being a brand which mainly uses an emblem on its products.

The results of the study show that if consumers are already using the brand, their brand preference is affected by the functional benefit of the brand's logo or emblem, regardless of the brand's use of logo or emblem. In view of this, particularly in the case of consumers who use the brand, it can be stated that while forming their brand preferences, they are interested in how far the brand meets their expectations. In this respect, they have a tendency to see the brand's logo or emblem as a symbol of this expectation. On the other hand, in the case of consumers who do not use the brand, the brand's use of logos or emblems can have a direct effect on consumers' brand preferences. 
According to the results of the study, in the case of consumers who do not use a given brand, those brands which make use of logos benefit in particular from the consumers' level of identification when they see the logo; however, brands which make use of emblems do not benefit significantly from any of the attitudes of consumers towards emblems. In view of this, particularly for consumers who do not already use the brand, the use of logos which include the brand's name, rather than emblems which only involve a symbol instead of a brand name, can be stated to provide a significant advantage for the brand in terms of brand preference. In line with the results of the study, if a choice is to be made between a logo and an emblem by a company, it is advisable to give preference to logos when establishing corporate branding. Such a preference can influence those consumers to choose the brand who do not already use it. In addition, the necessity, which is demonstrated by the results of this study, of treating the concepts logos and emblems separately, should be acknowledged and given serious consideration by researchers who conduct studies on this topic in the future.

\section{References}

[1] Rivers, Charlotte. (2003). Identify: Building Brands Through Letterhead Logo and Business Cards, Switzerland, RotoVision.

[2] Okay, Ayla. (2008) Kurum Kimliği, İstanbul, MediaCat.

[3] Watkins, B. A. \& Gonzenbach, W. J. (2013). “Assessing University Brand Personality Through Logos: An Analysis of the Use of Academics and Athletics in University Branding", Journal of Marketing for Higher Education, vol.23, issue.1, pp.15-33.

[4] Henderson, P. W. \& Cote, J. A. (1998). “Guidelines for Selecting or Modifying Logos”, Journal of Marketing, vol.62, pp.14-30.

[5] Chevalier, M.\& Mazzalovo, G. (2004). Pro Logo: Brands as a Factor of Progress, France, Palgrave.

[6] Airey, D. (2010). Logo Design Love: A guide to Creating Iconic Brand Identities, Berkeley, New Riders.

[7] Klein, N. (2001). No Logo, UK, Flamingo.

[8] Keller, K. L. (1993). “Conceptualizing, Measuring, and Managing Customer-Based Brand Equity", Journal of Marketing, vol.57, issue.1, pp.1-22.

[9] Rodriguez, L., Asoro, R. L., Lee, S. \& Sar, S. (2013). "Gestalt Principles in Destination Logos and Their Influence on People's Recognition and Intention to Visit a Country", Online Journal of Communication and Media Technologies, vol.3, issue.1, pp. 91-107.

[10] Becer, E. (2002). İletişim ve Grafik Tasarım, Ankara, Dost Kitabevi. 
[11] Keller, K. L. (2008). Strategic Brand Management: Building, Measuring, and Managing Brand Equity, Upper Saddle River, Pearson Education.

[12] Buttle, H. \& Westoby, N. (2006). "Brand Logo and Name Association: It's all in the Name”, Applied Cognitive Psychology, vol.20, issue 9, pp.1181-1194.

[13] Babür Tosun, N. (2014). Marka Yönetimi, İstanbul, Beta Basım.

[14] Lury, C. (2004). Brands: The Logos of the Global Economy, UK, Taylor \& Francis Routledge.

[15] Solomon, M. R., Bamossy, G. J., Askegaard, S. T. \& Hogg, M. K. (2013). Consumer Behaviour: A European Perspective, England, Pearson Education.

[16] Koç, E. (2012). Tüketici Davranışı ve Pazarlama Stratejileri: Global ve Yerel Yaklaşım, Ankara, Seçkin Yayıncılık, 2012.

[17] Odabaşı, Y. \& Barış, G. (2007). Tüketici Davranışı, İstanbul, Kapital Medya Hizmetleri,.

[18] Park, C. W., Eisingerich, A. B., Pol, G. \& Park, J.W. (2013). “The Role of Brand Logos in Firm Performance”, Journal of Business Research, vol.66, pp.180-187.

[19] Arnould, Eric J., Price, L. \& Zinkhan, G. M., (2004). Consumers, USA, Mc Graw Hill.

[20] Page, C. \& Herr, P. M. (2002). “An Investigation of the Processes by Which Product Design and Brand Strength Interact to Determine Initial Affect and Quality Judgments", Journal of Consumer Psychology, vol.12, issue.2, pp.133-147.

[21] Walsh, M. F., Winterich, K. P. \& Mittal, V. (2011). "How re-designing angular logos to be rounded shapes brand attitude: consumer brand commitment and self-construal", Journal of Consumer Marketing, vol.28, no.6, pp.438- 447.

[22] Gerrard, C., Janssen, M., Smith, L., Hamm, U. \& Padel, S. (2013).“UK Consumer Reactions to Organic Certification Logos”, British Food Journal, vol.115, issue.5, pp.727-742.

[23] Van Riel, C., Van den Ban, A. \& Heijmans, E. J. (2011). "The Added Value of Corporate Logos: An Empirical Study”. European Journal of Marketing, vol.35, no.3/4, pp.428-440.

[24] Fischer, P. M., Schwartz, M. P., Richards, J. W., Goldstein, A. O. \& Rojas, T. H. (1991). “Brand Logo Recognition by Children Aged 3 to 6 Years", The Journal of the American Medical Association, vol.266, no.22, pp.3145-3148.

[25] Kopelman, C.A, Roberts, L.M. \& Adab, P. (2007). "Advertising of food to children: is brand logo recognition related to their food knowledge, eating behaviours and food preferences?" Journal of Public Health, vol.29, no.4, pp.358-367.

[26] Sirgy, M. J., Grewal, D., Mangleburg, T. F., Park, J., Chon, K., Claiborne, C.B., Johar, J.S. \& Berkman, H. (1994). “Assessing the Predictive Validity of Two Methods of Measuring Self-Image Congruence", Journal of the Academy of Marketing Science, vol.25, no.3 , pp.229-41. 
[27] Westbrook, R. A. \& Oliver, R. L.. (1981). “Developing Better Measures of Consumer Satisfaction: Some Preliminary Results”, Advances in Consumer Research. Ed: Ann Arbor. MI: Association for Consumer Research, vol.8, issue.1, pp.94-99.

[28] Putrevu, S. \& Lord, K. R. (1994). “Comparative and Noncomparative Advertising: Attitudinal Effects Under Cognitive and Affective Involvement Conditions”, Journal of Advertising, vol.23, issue.2, pp.77-90.

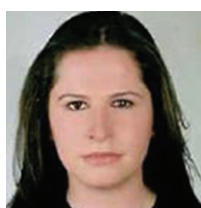

Sevda DENEÇLI - sevda.denecli@nisantasi.edu.tr

Sevda Deneçli graduated from F.M.V. Işıı University, Department of Business Administration in 2004. She got her master degree on Public Relations at Marmara University. In 2012, with dissertation of "The Role of Brand Extension on Corporate Reputation" she got her Ph.D. in the field of Public Relations at Marmara University. She is Assist. Prof. Dr. in Public Relations and Advertising at Nişantaşı University. Her research areas are brand, corporate social responsibility and social media. 
